\title{
METODE ESTD UNTUK PENGAMBILAN KEPUTUSAN GO/NO-GO EKSEKUSI IDE / RENCANA BISNIS PADA ERA INDUSTRI 4.0
}

\author{
Candra Taufik ${ }^{1}$ \\ Politeknik Piksi Ganesha \\ ctaufik@gmail.com \\ M. Yusuf Sanny ${ }^{2}$ \\ Politeknik Piksi Ganesha \\ yusufsanny.ys@gmail.com
}

\begin{abstract}
Abstrak - Industry 4.0 memberikan peluang disrupsi teknologi terjadi semakin cepat. Teknologi yang muncul beberapa tahun lalu mungkin sudah tergantikan dengan teknologi terbaru, dan teknologi yang muncul saat ini akan tergantikan oleh teknologi yang lahir beberapa tahun ke depan. Bisnis dapat dipengaruhi oleh adanya disrupsi teknologi tersebut. Satu sisi industri 4.0 dapat menciptakan peluang-peluang usaha baru, namun disisi yang lain dapat menjadi ancaman bagi usaha-usaha yang telah jalan. Calon pengusaha dapat memiliki ide / rencana bisnis baru, sementara pengusaha perlu memiliki ide / rencana bisnis baru untuk dapat mempertahankan bisnis yang telah dilaksanakan. Para pengusaha perlu beradaptasi terhadap ancamanancaman yang dihadapi dengan senantiasa membuat inovasi-inovasi baru dalam bisnisnya terutama pada era industri 4.0 ini. Eksekusi ide / rencana bisnis dapat langsung dilaksanakan oleh pemiliknya dan kemudian akan menghadapi dua kemungkinan, yaitu kesuksesan atau kegagalan. Statistik menunjukkan bahwa tidak sedikit yang mengalami kegagalan. Banyak juga pengusaha / calon pengusaha yang merasa khawatir terjadi kegagalan sehingga tidak mengeksekusi ide / rencana bisnisnya. Penelitian ini bertujuan untuk mengetahui efektivitas Metode Pengambilan Keputusan Lanjut / Tidak Lanjut (Go/No-Go) dalam eksekusi ide / rencana bisnis pada era Industri 4.0 sebagai alternatif metode selain metode QuickScreen \& VOSE (Timmons, 2011), Studi Kelayakan dan Analisis SWOT. Metode Go/No-Go yang dimaksud terdiri dari Explore / Eksplorasi, Select / Pilih, Test / Uji dan Decide / Putuskan atau disingkat ESTD. Dalam penelitian sebelumnya metode tersebut diimplementasikan oleh sejumlah responden dalam pengambilan keputusan lanjut / tidak lanjutnya eksekusi ide / rencana bisnis mereka. Hasil penelitian diharapkan dapat memperkaya teori kewirausahaan dalam proses penyaringan peluang bisnis atau penentuan peluang bisnis (venture opportunity) yang benar. Metode penelitian yang dipergunakan adalah metode kualitatif dan ditujukan untuk menjawab pertanyaan "Dapatkah metode ESTD dipergunakan sebagai metode pengambilan keputusan go/no-go pada era industri 4.0". Hasil penelitian memberikan bukti bahwa metode ESTD memiliki beberapa kriteria sehingga dapat digunakan sebagai metode pengambilan keputusan atau pun sebagai metode penyaringan ide / rencana bisnis pada era Industry 4.0.
\end{abstract}

Kata Kunci: Go/No-Go, metode, pengambilan keputusan, peluang bisnis, ide, rencana 
Abstract - Industry 4.0 provides opportunities for technological disruption to occur more quickly. The technology that emerged a few years ago may have been replaced by the latest technology, and the technology that emerges today will be replaced by the technology that was born in the next few years. Business can be affected by the disruption of the technology. One side of industry 4.0 can create new business opportunities, but on the other hand it can be a threat to businesses that have gone ahead. Prospective entrepreneurs can have new ideas / business plans, while entrepreneurs need to have new ideas / business plans to be able to maintain the business that has been implemented. Entrepreneurs need to adapt to the threats they face by always making new innovations in their business, especially in this industry 4.0 era. Execution of ideas / business plans can be directly carried out by the owner and then will face two possibilities, namely success or failure. Statistics show that not a few who experience failure. There are also many entrepreneurs / prospective entrepreneurs who feel worried about failure so they do not execute their ideas / business plans. This study aims to determine the effectiveness of the Go / No-Go Decision Making Method in the execution of business ideas / plans in the Industrial 4.0 era as an alternative method besides the QuickScreen \& VOSE method (Timmons, 2011), Feasibility Study and SWOT Analysis. The Go / No-Go method referred to consists of Explore / Exploration, Select / Select, Test / Decide / Decide or abbreviated ESTD. In the previous research, this method was implemented by a number of respondents in their decision making / not continuing the execution of their ideas / business plans. The results of the study are expected to be able to enrich entrepreneurship theory in the process of filtering business opportunities or determining the right business opportunities (venture opportunity). The research method used is a qualitative method and is intended to answer the question "Can the ESD method be used as a go / no-go decision making method in the industrial era 4.0". The results of the study provide evidence that the ESTD method has several criteria so that it can be used as a decision-making method or as a method of filtering ideas / business plans in the Industry 4.0 era.

Keywords: Go / No-Go, methods, decision making, business opportunities, ideas, plans

\section{PENDAHULUAN}

Statistik yang dilaksanakan di Amerika menyebutkan persentase perusahaan-perusahaan yang dapat bertahan dari sejak berdirinya perusahaan tersebut. Schaefer (2011) menyebutkan bahwa dua pertiga perusahaan yang berdiri dapat bertahan selama 2 tahun dan $44 \%$ bertahan sedikitnya 4 tahun. Lebih jauh lagi diyakini bahwa $50 \%$ bisnis gagal pada tahun pertama dan $95 \%$ gagal dalam selang 5 tahun.
Schaefer (2011) mengutarakan bahwa penyebab kegagalan dari suatu usaha adalah kurangnya perencanaan. Kebanyakan bisnis kecil itu gagal karena kesalahan mendasar dari rencana bisnis mereka. Rencana bisnis itu harus realistik, berbasis informasi yang baru, akurat, dan proyeksi untuk masa depan Ide atau rencana bisnis yang dibuat oleh calon wirausahawan akan menemui titik di mana calon wirausahawan tersebut perlu memutuskan eksekusi ide / rencana tersebut. 
Peluang usaha (venture opportunity) yang telah ada baik berupa ide maupun rencana bisnis tidak dapat begitu saja dieksekusi, sebab risiko yang mungkin muncul dapat bernilai cukup besar. Dengan pertimbangan risiko tersebut maka kemungkinan keputusan yang akan dibuat adalah lanjut atau tidak lanjut (Go/No-Go). Begitu dieksekusi lanjut, maka kemungkinan yang dihadapi adalah sukses atau gagal.

Pengambilan

keputusan Lanjut/Tidak Lanjut ini pun tidak hanya ditemui oleh para calon wirausahawan, para pengusaha yang telah menjalankan bisnis pun akan menemukannya ketika mereka melakukan inovasi pada bisnisnya.

Dalam rangka mengembangkan dan mempertahankan bisnisnya, maka para pengusaha akan senantiasa melakukan inovasi, menemukan ide-ide bisnis yang baru, sehingga mereka dapat bertahan di tengah persaingan bisnis yang semakin lama semakin ketat.

Pengusaha akan selalu bertemu risiko selama melaksanakan bisnisnya, namun ketika menemui risiko pengusaha memiliki sikap "Ingin Mengambil Risiko" (Want to Take Risk). Hal ini berbeda dari manajer atau pekerja yang bekerja di dalam suatu perusahaan, sebagaimana disebutkan oleh Koudstaal et, al. (2015) :

York dan Danes (2015) mengutarakan bahwa di dalam membuat keputusan, seorang pengusaha menjumpai batasan-batasan informasi, oleh karenanya mereka lebih menggunakan intuisi.

Kuratko (2016) menyebutkan bahwa ada dua fase yang sangat kritis untuk para pengusaha, yaitu prestart-up dan start-up. Menurutnya juga ada 5 faktor yang kritis yaitu : keunikan relatif dari usaha, ukuran investasi relatif saat startup, pertumbuhan penjualan atau profit yang diharapkan, ketersediaan produk selama prestart-up dan start-up, dan adanya pelanggan selama prestart-up dan start-up.

Pengukuran terhadap faktor-faktor kritis yang disebutkan oleh Kuratko (2016) di atas dapat kita anggap sebagai contoh pentingnya upaya untuk menilai ide / rencana bisnis dengan suatu metode.

Pada tahun 2007, sebuah konsorsium internet service provider (ISP) di Bandung memiliki ide / rencana bisnis untuk mengembangkan dan melindungi bisnis dari masing-masing perusahaan yang tergabung dalam konsorsium. Kajian mengenai kelayakan ide / rencana bisnis ISP tersebut melahirkan konsep Metode Pengambilan Keputusan Go/No-Go yang berisi 4 tahapan yang disingkat dengan ESTD yaitu Explore, Select, Test dan Decide. Metode tersebut kemudian disempurnakan pada tahun 2017 dalam penelitian berjudul "Metode Pengambilan Keputusan Go/No-Go Eksekusi Rencana Bisnis Bidang Software Development".

Beberapa metode untuk memperoleh keputusan lanjut atau tidaklanjut adalah Studi Kelayakan (Feasibility Study), SWOT Analysis, dan Metode QuickScreen \& Venture Opportunity Screening Exercises (VOSE). Dalam penelitian 2017, perusahaan-perusahaan yang diteliti tidak mempergunakan salah satu dari metode-metode tersebut. Mereka menggunakan metode sendiri yaitu menentukan asumsi-asumsi yang berkaitan dengan bisnisnya dan mencari fakta untuk setiap asumsi yang dibuat. Ada juga pengusaha yang mempergunakan Business Canvas Model untuk memberikan gambaran dari rencana bisnisnya. Pada intinya mereka berusaha untuk memperoleh keyakinan bahwa ide bisnisnya memang merupakan peluang bisnis yang tepat.

Metode ESTD merupakan metode pengambilan keputusan Go/No-Go eksekusi ide / rencana bisnis yang 
mengadopsi bagian-bagian tertentu dari metode-metode tersebut, yaitu penggunaan asumsi, pengujian asumsi dan pencarian fakta, serta dirancang agar mudah dipahami dan dipergunakan oleh calon pengusaha dan / atau pengusaha. Metode ini dibuat sebagai pendekatan terhadap metode yang dipergunakan oleh para pengusaha / objek penelitian 2017.

Hasil penelitian tahun 2017 menunjukkan adanya hal-hal khusus yang biasanya dilakukan oleh para pengusaha bidang Software Development / Teknologi Informasi dalam mengambil keputusan eksekusi suatu ide / rencana bisnis (Taufik, 2018). Keunikan dalam metode pengambilan keputusan tersebut perlu diuji-cobakan kepada para calon pengusaha baru agar mereka mendapatkan efektivitas dan efisiensi. Hal tersebut telah dilaksanakan pada penelitian terakhir.

Industry 4.0 memberikan peluangpeluang usaha baru bagi para calon pengusaha dan juga dapat menjadi suatu ancaman bagi pengusaha yang telah menjalankan usahanya. Baik para calon pengusaha maupun pengusaha yang telah ada perlu melakukan inovasi dan menciptakan ide-ide bisnis yang baru.

Potensi ekonomi dari industry 4.0 adalah sangat besar (Bartodziej, 2017).

Penggunaan solusi Industri 4.0 berdampak pada penurunan biaya, yaitu biaya modal, biaya energy dan biaya pegawai (Bartodziej, 2017). Bagi Negara dimana para pengusahanya merupakan pengguna solusi industry 4.0 sangat dimungkinkan untuk meningkatkan pendapatan Gross Domestic Product-nya (GDP).

Revolusi industry 4.0 ditandai dengan adanya internet of things dan internet of services yang diintegrasikan dengan lingkungan pabrik sebagaimana diutarakan oleh Gilchrist (2016).
Adanya era industry
4.0 menimbulkan pertanyaan, dapatkah metode ESTD menjadi alternatif metode pengambilan keputusan Go/No-Go dan juga menjadi metode penyaringan ide-ide bisnis yang mempergunakan solusi industry 4.0. Penelitian ini akan membahas mengenai hal tersebut dan diharapkan hasilnya akan lebih memperkaya teori kewirausahaan.

\section{KAJIAN LITERATUR}

Beberapa teori mendasari penelitian ini adalah Tahapan Inovasi, The Timmons Model, Screening Venture Opportunities, Metode Pengambilan Keputusan Go/NoGo (ESTD).

\section{Tahapan Inovasi}

Gambar 1 di bawah merupakan tahapan inovasi dan pembangkitan ide yang diciptakan oleh Cohendet dan Simons (2015). Terdapat 5 tahap dalam proses inovasi yang paralel dengan pembangkitan ide dan pengelolaan pengetahuan (knowledge management).

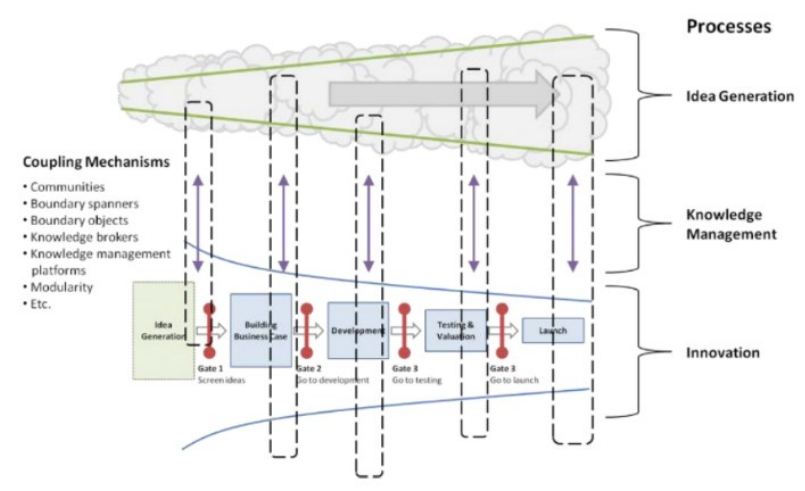

Gambar 1. Tahapan Inovasi dan Pembangkitan Ide

Menurut Cohendet dan Simons (2015) bahwa pembangkitan ide harus paralel dengan proses inovasi (building business case, development, testing \& valuation and launching). Terdapat dua hal yang dapat kita pahami, yaitu bahwa pembangkitan ide harus terus menerus dilakukan sementara inovasi sedang dilaksanakan, dan dalam pelaksanaan proses inovasi terdapat tahapan 
pengujian ide sebelum lanjut kepada tahapan launching.

Tahapan proses inovasi adalah sebagai berikut : pembangkitan ide-ide, pembangunan kasus bisnis, pengembangan, pengujian dan penilaian, dan terakhir adalah launching. Proses inovasi merupakan proses yang terjadi di dalam pendirian usaha, mempertahankan usaha dan pengembangan bisnis.

Objek penelitian ini merupakan para calon pengusaha yang terdiri dari mahasiswa atau karyawan / pekerja. Mereka memiliki gagasan berinovasi dan mencoba mempelajari bagaimana menjadi pengusaha. Ide yang dimiliki perlu diuji apakah memang merupakan suatu peluang atau bukan. Hal tersebut perlu dilakukan sebagaimana tahapan proses yang diciptakan Cohendet dan Simons (2015).

\section{The Timmons Model}

Model Proses Kewirausahaan yang diciptakan oleh Timmons (2011) menjelaskan bahwa suatu usaha perlu memiliki tiga elemen penting, yaitu : Peluang (Opportunity), Sumber Daya (Resources) dan Team. Ketiga hal tersebut adalah syarat mutlak dalam menjalankan suatu usaha.

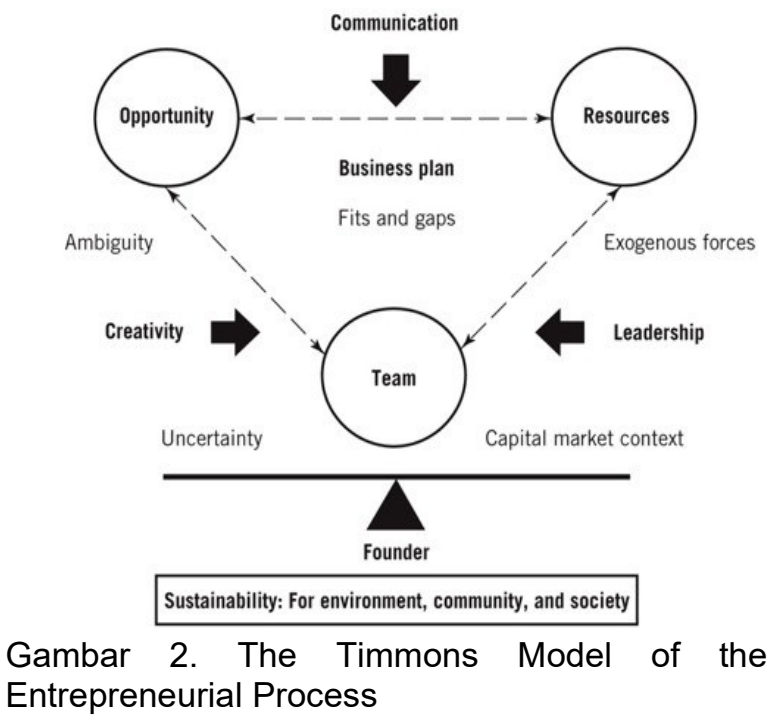

Gambar 2 adalah Model Proses Kewirausahaan Timmons, memperlihatkan bahwa di antara peluang, sumber daya dan team perlu ada komunikasi, kreativitas dan kepemimpinan. Bagi pendiri, terdapat pertimbangan antara ketidakpastian dan konteks pasar modal.

Timmons (2011) : Peluang adalah hatinya proses kewirausahaan, dan pengusaha dan penemu yang sukses tahu bahwa ide yang bagus tidak selalu merupakan peluang yang bagus.

Meskipun memiliki peluang, team dan sumber daya, ide bisnis tidak dapat langsung dieksekusi. Ide bisnis perlu melewati proses penyaringan peluang usaha terlebih dahulu untuk meningkatkan peluang kesuksesan dan menekan risiko kegagalan. Semangat pengusaha akan tinggi ketika merasakan peluang usaha sangat menjanjikan, namun pada kenyataannya banyak pengusaha yang rugi setelah melaksanakan ide / rencana usahanya tanpa pertimbangan yang lebih matang.

\section{Screening Venture Opportunities}

Timmons (2011) menyebutkan bahwa kegagalan pada suatu bisnis banyak disebabkan oleh karena para pengusaha tidak fokus pada peluang yang benar. Ide / rencana bisnis yang dianggap bagus belum tentu merupakan peluang bisnis yang benar.

Dalam menyaring peluang-peluang usaha, Timmons (2011) menggunakan beberapa kriteria yang perlu dipertimbangkan, yaitu : Industri dan Pasar, Ekonomi, Isu panen, Isu Keuntungan, Tim Pengelola, Isu Cacat Fatal Kriteria Personal, dan Perbedaan Strategis. Kriteria-kriteria tersebut masih diuraikan lagi lebih rinci oleh beliau dan dibuat demikian agar dapat mencakup berbagai aspek yang perlu dipertimbangkan dalam bisnis. 
Metode QuickScreen menilai beberapa kriteria utama sebagaimana dijelaskan sebelumnya, yaitu : market and margin, competitive advantages dan value creation and realization issues. Kriteria-kriteria tersebut diuraikan lebih rinci dalam bentuk tabel yang memiliki kolom potensi tinggi dan rendah untuk setiap uraian. Dengan metode QuickScreen diharapkan akan mendapatkan keputusan penyaringan satu ide/peluang dalam satu jam, sehingga beberapa ide/peluang dapat disaring dan dipilih mana yang terbaik.

Setelah melewati QuickScreen, calon pengusaha perlu lebih mendalami seluk beluk usaha yang dianggap memiliki potensi bagus dengan menggunakan metode VOSE.

Metode VOSE merupakan metode yang terdiri dari 12 kegiatan (Exercises) dan membutuhkan waktu yang lama. Kegiatan-kegiatan VOSE yaitu mencakup pengisian formulir-formulir : opportunity concept and strategy statement, venture opportunity profile, opportunity shaping research and exercise, customer contact research and exercise, mining the value chain-defining the "white space", economics of the business, capital and harvest-how will you realize dollars from the venture, competitive landscape-your strategic analysis, founder's commitment, flaws, assumptions, and downside consequences - risk reconsidered, action steps - setting a week-by-week schedule, dan terakhir four anchors revisited.

Dengan memperhatikan jumlah kegiatan pengisian formulir metode VOSE, waktu yang diperlukan untuk melaksanakan metode ini diperkirakan tidak sedikit. Namun diperkirakan bahwa tingkat keyakinan terhadap keputusan yang diperoleh setelah menyelesaikan metode VOSE sangat tinggi.

Mengenai metode VOSE ini, Timmons (2011) menjelaskan : Dengan menyelesaikan semua kegiatan/latihan- latihan VOSE, maka hal ini akan membantu dalam menentukan apakah peluangnya cukup menarik atau tidak.

Selain metode yang disampaikan oleh Timmons, menurut Suryana (2012), terdapat dua alat bantu analisis yang dapat dipergunakan untuk menentukan tepat tidaknya suatu rencana bisnis, yaitu studi kelayakan dan analisis kekuatankelemahan-peluang-ancaman / strengthweakness-opportunity-threat (SWOT).

Sunyoto (2014) menyebutkan bahwa hasil studi kelayakan secara prinsip dapat dipergunakan untuk beberapa hal, yaitu : memulai usaha baru seperti membuka toko, membangun pabrik, memulai perusahaan jasa / layanan; mengembangkan bisnis yang ada, contohnya adalah meningkatkan kapasitas pabrik, ekspansi skala bisnis, penggantian peralatan / mesin, penambahan mesin baru, ekspansi lingkup bisnis dan lain-lain; pemilihan tipe-tipe bisnis, investasi, atau projek yang paling menguntungkan, seperti pemilihan bisnis perdagangan, pemilihan barang-barang atau produk atau bisnis jasa, pabrikasi atau perakitan, projek $A$ atau projek $B$, dan lain-lain.

Studi Kelayakan menjelaskan aspek-aspek bisnis / proyek dalam bentuk uraian yang rinci, dan kemudian melakukan pengambilan kesimpulan berdasarkan pertimbangan terhadap beberapa aspek penting. Sementara itu analisis SWOT mengumpulkan asumsiasumsi dan fakta yang berkaitan dengan hal yang akan diputuskan, kemudian melakukan analisis untuk setiap aspek kekuatan, kelemahan, peluang dan ancaman serta hubungan di antara aspek-aspek tersebut.

Metode ScreenQuick, VOSE, Studi Kelayakan dan SWOT dapat menjadi alternatif pilihan metode sebagai alat bantu untuk pengambilan keputusan Go/No-Go. Dalam penelitian ini dipergunakan metode ESTD 
sebagaimana yang disebutkan dalam ruang lingkup permasalahan.

\section{Metode Pengambilan Keputusan Go/No-Go (ESTD)}

Usulan metode pengambilan keputusan Go/No-Go (ESTD) ini merupakan upaya untuk mempermudah proses pengambilan keputusan sebagai alternatif lain dari metode-metode yang dijelaskan pada sub bab 3.3 di atas. Gambar 3 adalah Metode ESTD yang mencakup 4 tahap yaitu explore, select, test, dan decide.
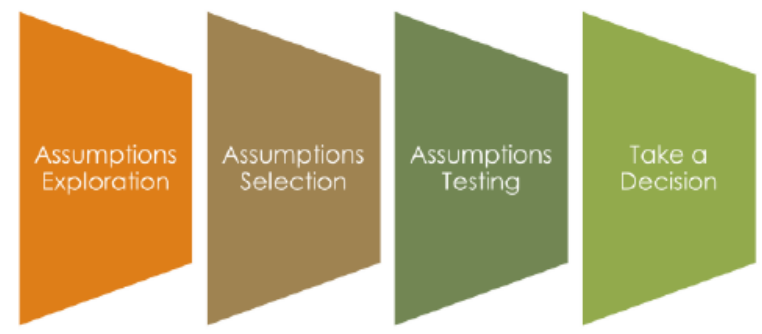

Gambar 3. Metode ESTD (Taufik, 2018)

Pada tahap eksplorasi / explore tim usaha mendiskusikan hal-hal / asumsiasumsi yang diperkirakan berpengaruh terhadap ide / rencana bisnis. Asumsiasumsi tersebut merupakan hal-hal yang berkaitan dengan kriteria-kriteria : market, produk, teknologi, ekonomi, kompetisi, organisasi, dan lingkungan. Kriteriakriteria tersebut dapat juga diganti dengan kriteria yang digunakan oleh Timmons (2011).

Menurut Duening (2014) penilaian peluang hanya dilakukan pada peluang dan market saja dan tidak kepada keuangan, marketing atau organisasi. Namun pada kenyataannya kriteriakriteria lainnya diperlukan sebagai bahan pertimbangan.

Widyasthana (2017) menyebutkan beberapa kriteria untuk menilai start-up dan mengurangi risiko : team manajemen, keaslian produk, kemampuan intelektual, lokasi geografis dan koherensi menjadi parameter- parameter yang juga perlu dipertimbangkan.

Tahap pilih / select berarti tim pengusaha melakukan pemilihan asumsiasumsi yang paling penting dari semua asumsi yang telah dibuat pada tahap explore. Sementara tahap uji / test berarti menguji setiap asumsi yang terpilih dengan mencari informasi yang nyata. Beberapa perusahaan IT melakukan : pengukuran tingkat kesulitan pembuatan produk, membuat produk/prototipe dan mencobanya kepada user, melakukan market test, dan menginterviu prospek.

Tahap terakhir yaitu putuskan / decide, tim pengusaha membuat kriteria keputusan Go/No-Go terlebih dahulu, kemudian dengan mempertimbangkan hasil pengujian terhadap asumsi-asumsi terpilih maka mereka dapat membuat keputusan mengenai lanjut / tidak lanjutnya eksekusi bisnis.

Gambar 4 adalah metode ESTD yang khusus ditemukan pada penelitian tahun 2017. Dalam tahap explore, para pengusaha melakukan eksplorasi dengan cara survey, pemetaan model kanvas bisnis, dan melakukan diskusi internal. Pada tahap select beberapa kegiatan yang dapat dilakukan adalah : diskusi internal, diskusi eksternal / dengan pihak luar, pemetan model kanvas bisnis, melakukan benchmarking terhadap perusahaan sejenis.

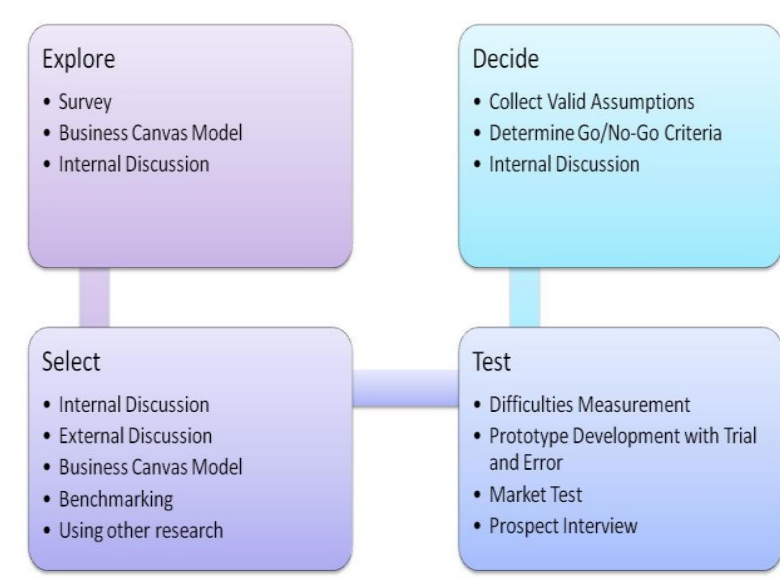

Gambar 4. Metode ESTD Bidang IT (Taufik, 2018) 
Tahap berikutnya yaitu pengujian / test mereka hanya melakukan sedikit kegiatan untuk meyakinkan bahwa asumsi-asumsinya memang tepat atau tidak, yaitu mengukur tingkat kesulitan dalam pembuatan produk atau jasa, melakukan pembuatan prototype dan mengujinya pada user, melakukan uji pasar, dan melakukan wawancara terhadap prospek. Terakhir, tahap pengambilan keputusan dari hasil pengujian, para pengusaha IT mengumpulkan asumsi-asumsi yang valid, membuat kriteria lanjut / tidaklanjutnya yang tergantung kepada hasil pengujian asumsi, dan melakukan diskusi internal.

Pada penelitian sebelumnya, metode ESTD diimplementasikan oleh sejumlah responden dan dibuat dalam bentuk file excel yang dilengkapi dengan contoh-contoh asumsi dan kriteria pengambilan keputusan. Hal tersebut dimaksudkan untuk mempermudah penggunanya.

\section{METODE PENELITIAN}

Metode penelitian yang dipergunakan adalah metode kualitatif, terdiri dari : merancang pertanyaan penelitian; pengumpulan data penelitian; analisis dan interpretasi data; validasi data dan verifikasi; dan terakhir melakukan generalisasi.

Penelitian ini ditujukan untuk menjawab pertanyaan : "Dapatkah metode ESTD dipergunakan untuk melakukan pengambilan keputusan lanjut / tidak-lanjut eksekusi ide / rencana bisnis pada era industry 4.0".

Data penelitian dikumpulkan dari hasil penelitian sebelumnya, dari studi literature tentang industry 4.0 dan dampaknya terhadap bisnis, serta metode ESTD itu sendiri yang nantinya dilakukan analisis terhadap tahapantahapan di dalamnya.

\section{HASIL DAN PEMBAHASAN}

Untuk menjawab pertanyaan penelitian, perlu ditentukan terlebih dahulu kriteria apa yang perlu dimiliki oleh metode pengambilan keputusan go / nogo pada era industry 4.0.

Schumacher (2016) melakukan penelitian tentang model kematangan perusahaan dalam menghadapi industri 4.0. Yang dimaksud dengan kematangan perusahaan industri adalah kondisi adanya kelebihan-kelebihan secara internal maupun eksternal yang mendukung industry 4.0 seperti integrasi vertikal dan horizontal sistem manufaktur, sebagaimana halnya integrasi digital dari keteknikan untuk seluruh level rantai nilai. Jadi kriteria pertama adalah perlunya menambahkan asumsi dan pengujian mengenai kematangan perusahaan dalam menghadapi industry 4.0.

Terkait dengan hal tersebut, metode pengambilan keputusan lanjut / tidaklanjut eksekusi ide / rencana bisnis harus mempertimbangkan tentang kematangan perusahaan dalam menghadapi industry 4.0. Metode ESTD telah memasukkan kelompok asumsi Teknologi yang dapat dikembangkan lebih jauh oleh penggunanya. Hal ini berarti metode ESTD telah memenuhi kriteria tersebut.

Industri 4.0 sering dibandingkan dengan peningkatan kemunculan gangguan (disruption) dalam produksi seperti revolusi industri yang diprakarsai oleh uap, listrik, dll. (Schmidt, 2015). Dalam Industri 4.0, TI adalah pendorong perubahan dan inovasi dalam hal proses dan teknologi, namun itu bukan prasyarat (Wyrwicka, 2017).

Selain mempengaruhi peningkatan disrupsi teknologi, industry 4.0 juga dapat menyebabkan perubahan model bisnis. Di Industry 4.0, model bisnis baru yang berkembang sangat didorong oleh 
penggunaan data pintar untuk menawarkan layanan baru (Stock, 2016).

Industri 4.0 juga dapat menimbulkan ancaman bagi perusahaan manufaktur. Banyak negara maju yang basis ekonominya adalah industri manufaktur telah melakukan upaya untuk mentransformasikan ekonomi mereka dan menghidupkan kembali industri tersebut. Mereka menderita ancaman dari pasar negara berkembang dan rantai pasokan manufaktur global (Lee, 2014).

Dengan memperhatikan permasalahan-permasalahan adanya disrupsi dan perubahan model bisnis yang meningkat dan cepat maka kriteriakriteria lainnya yang harus dimiliki oleh metode pengambilan keputusan lanjut / tidak-lanjut adalah fleksibel, mudah dipergunakan, dan efektif.

Untuk masalah fleksibilitas, metode ESTD dalam bentuk file excel berisi tahapan-tahapan yang dapat dimodifikasi isinya sesuai kondisi yang dihadapi oleh penggunanya. Pengguna metode tersebut dapat menggunakan contoh asumsi dan membuat asumsi-asumsi yang diperlukan. Begitu juga untuk pengujian maupun pengambilan keputusan, pengguna dapat menentukan kriteria-kriteria pengambilan keputusan sesudah hasil diskusi internal tim usahanya.

Dari penelitian sebelumnya (Taufik, 2019) diketahui bahwa waktu rata-rata pengambilan keputusan Go/No-Go adalah 6.39 hari dan standard deviasi 1.47 hari. Tabel 1 di bawah ini merupakan data statistik mengenai durasi penggunaan metode ESTD. Untuk tingkat keyakinan $90 \%$ diperoleh range rata-rata waktu penggunaan metode ESTD 4.45 s/d 8.33 hari. Sekitar $89 \%$ dari responden menyatakan bahwa metode pengambilan keputusan Go/No-Go ini mudah dipahami dan dipergunakan.

Tabel 1. Durasi Penggunaan Metode ESTD (Taufik, 2019)

\begin{tabular}{ll}
\hline Item & Nilai \\
\hline Rata-rata & 6.39 hari \\
Standard Deviasi & 1.47 hari \\
Range untuk Tingkat & $4.45 \mathrm{~s} / \mathrm{d} 8.33$ hari \\
Keyakinan $90 \%$ & \\
\hline
\end{tabular}

Sekitar $89 \%$ responden yang mengisi survei pasca penggunaan metode ESTD menyatakan bahwa metode ini mudah dipahami dan dipergunakan. Gambar 5 menampilkan statistik mengenai kemudahan metode ESTD (Taufik, 2019).

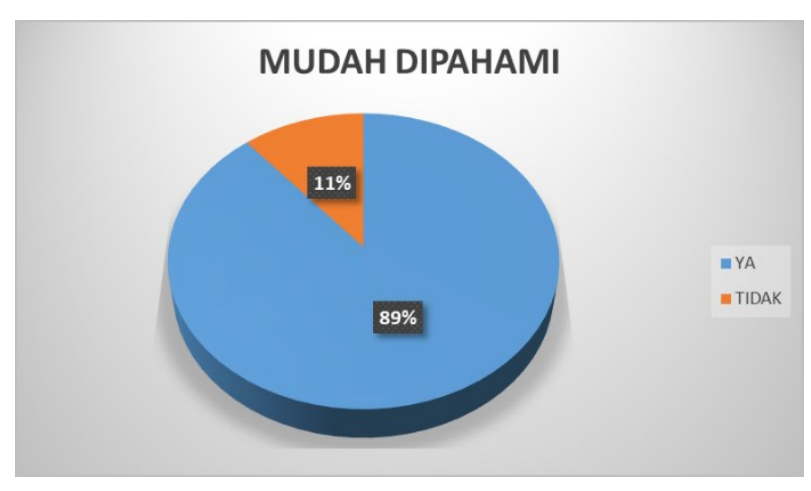

Gambar 5. Kemudahan Memahami Metode ESTD (Taufik, 2019)

Dengan melihat data penelitian tersebut, maka kriteria kemudahan penggunaan dan efektivitas telah dipenuhi.

Metode pengambilan keputusan dan penyaringan ide / rencana bisnis lainnya seperti QuickScreen \& VOSE, Studi Kelayakan, dan SWOT dapat dipergunakan, namun dalam penelitian ini difokuskan kepada implementasi / penggunaan metode ESTD.

Industri 4.0 menyebabkan terjadinya disrupsi teknologi menjadi lebih cepat. Bagi perusahaan manufaktur yang tidak mampu beradaptasi terhadap era industry 4.0 atau yang belum memiliki kematangan menghadapinya, mereka akan mengalami kompetisi yang lebih berat. Bagi perusahaan atau calon pengusaha yang mampu mengadopsi industry 4.0, mereka dapat menghasilkan 
model bisnis baru sehingga dapat menciptakan ide / rencana bisnis yang mampu mempertahankan bisnisnya.

Untuk secara aktif membentuk transformasi, produsen dan pemasok sistem harus mengambil tindakan tegas untuk merangkul sembilan pilar kemajuan teknologi (Rüßmann, 2015). 9 pilar yang dimaksud adalah Autonomous robots,

Augmented reality, Big data and analytics Additive manufacturing, The cloud Cybersecurity, Simulation, Horizontal and vertical system integration, dan The Industrial Internet of things.

Dalam menghadapi era industry 4.0 ini perlu ada penyesuaian dalam bidang pendidikan, yaitu menyesuaikan kurikulum sekolah, pelatihan, dan program universitas dan memperkuat pendekatan kewirausahaan untuk meningkatkan keterampilan terkait IT dan kemampuan inovasi tenaga kerja (Rüßmann, 2015).

\section{PENUTUP}

Metode ESTD telah memenuhi kriteria-kriteria yang diperlukan untuk sebuah metode pengambilan keputusan lanjut / tidak lanjutnya eksekusi ide / rencana bisnis pada era industry 4.0 yaitu : mempertimbangkan kondisi kematangan menghadapi industry 4.0, fleksibilitas tinggi, mudah dipergunakan dan efektif. Oleh karena itu metode ESTD dapat dipergunakan sebagai alternatif metode pengambilan keputusan lanjut / tidak-lanjut eksekusi ide / rencana bisnis pada era industry 4.0.

industry 4.0 menyebabkan peningkatan disrupsi teknologi sehingga kompetisi bisnis semakin besar terutama pada bidang manufaktur atau yang menggunakan teknologi sebagai domain bisnisnya. Untuk itu semua pelaku usaha perlu untuk dapat mengadopsi teknologi yang diperlukan sehingga memiliki kesiapan menghadapi era industry 4.0.

\section{ACKNOWLEDGEMENTS}

Terima kasih kepada Kementerian Ristek Dikti yang telah menyetujui penelitian dosen pemula ini untuk dilaksanakan dengan menggunakan dana DIPA DRPM Tahun 2019.

\section{DAFTAR PUSTAKA}

Bartodziej, C. J. (2017). The concept industry 4.0. In The Concept Industry 4.0 (pp. 27-50). Springer Gabler, Wiesbaden.

Cohendet, P., \& Simon, L. (2015). Introduction to the Special Issue on Creativity in Innovation. Technology Innovation Management Review, 5(7), 12-23.

Duening, T. N., Hisrich, R. A., \& Lechter, M. A. (2014). Technology Entrepreneurship: Taking Innovation to the Marketplace. Academic Press.

Gilchrist, A. (2016). Industry 4.0: the industrial internet of things. Apress. Koudstaal, M., Sloof, R., \& Van Praag, M. (2015). Risk, uncertainty, and entrepreneurship: Evi-dence from a lab-in-the-field experiment. Management Science, 62(10), 28972915.

Kuratko, D. F. (2016). Entrepreneurship: Theory, process, and practice. Cengage Learning.

Lee, J., Kao, H. A., \& Yang, S. (2014). Service innovation and smart analytics for industry 4.0 and big data environment. Procedia Cirp, 16, 3-8.

Rüßmann, M., Lorenz, M., Gerbert, P., Waldner, M., Justus, J., Engel, P., \& Harnisch, M. (2015). Industry 4.0: The future of productivity and growth in manufacturing 
industries. Boston Consulting Group, 9(1), 54-89.

Schaefer, P. (2011). The seven pitfalls of business failure and how to avoid them. Attard Com-munications.

Schmidt, R., Möhring, M., Härting, R. C., Reichstein, C., Neumaier, P., \& Jozinović, P. (2015, June). Industry 4.0-potentials for creating smart products: empirical research results. In International Conference on Business Information Systems (pp. 16-27). Springer, Cham.

Schumacher, A., Erol, S., \& Sihn, W. (2016). A maturity model for assessing Industry 4.0 readiness and maturity of manufacturing enterprises. Procedia Cirp, 52, 161166.

Stock, T., \& Seliger, G. (2016). Opportunities of sustainable manufacturing in industry 4.0. Procedia Cirp, 40, 536-541.

Sunyoto, D. (2014). Studi kelayakan bisnis. Penerbit CAPS (Center of Academic Publishing ser-vice). Yogyakarta.

Suryana, Y., \& Bayu, K. (2012). Kewirausahaan: Pendekatan

Karakteristik Wirausahawan Sukses Ed. 2. Kencana.

Taufik, C., \& Karyadi (2018). Go/No-Go Decision-Making Method on Business Development of Software Development in Indonesia. Journal of Entrepreneurship, Business and Economics, 6(2), 71-90.

Taufik, C., \& Sanny, Y. (2019). Implementasi Metode Pengambilan Keputusan Go/No-Go dalam Eksekusi Ide Rencana Bisnis Bidang Teknologi Informasi. Sebatik, 23(2), 654-662.

Timmons, J., Smollen, L. E., \& Dingee, A. L. M. (2011). New Venture Creation: A Guide to Entrepreneurship. University of Singapore.

Widyasthana, G. N. S., Wibisono, D., Purwanegara, M. S., Siallagan, M., \& Sukmawati, P. (2017). Corporate venture capital strategy for selecting start-up investments in Indonesia using an agent-based model: Cases of a mobile application start-up, payment solution start-up and digital advertising start-up. Journal of Entrepreneurship Education.

Wyrwicka, M. K., \& Mrugalska, B. (2017). “Industry 4.0" - towards opportunities and challenges of implementation. DEStech Transactions on Engineering and Technology Research, (icpr).

York, J. L., \& Danes, J. E. (2015). Customer Development, Innovation, and Decision-Making Biases int he Lean Startup. Journal of Small Business Strategy, 24(2), 21-40. 